\title{
HUBUNGAN USIA MENARCHE DENGAN KEJADIAN KANKER OVARIUM
}

\author{
Marina Tandarto'), Erwin Ginting ${ }^{2)}$, M. Khairul Nuryanto ${ }^{3)}$ \\ ${ }^{1}$ Fakultas Kedokteran Universitas Mulawarman, Samarinda, Kalimantan Timur, \\ Indonesia \\ 2Dosen Fakultas Kedokteran Universitas Mulawarman, RSUD Abdul Wahab \\ Sjahranie, Samarinda, Kalimantan Timur, Indonesia \\ ${ }^{3}$ Departemen IImu Kesehatan dan Kedokteran Komunitas, Fakultas Kedokteran, \\ Universitas Mulawarman, Samarinda, Kalimantan Timur, Indonesia
}

Email : rinatandarto@gmail.com

\begin{abstract}
Ovarian cancer is the $7^{\text {th }}$ most common cancer and the $8^{\text {th }}$ most common cause of death in women worldwide. In the year 2012, Indonesia constitute as a country with the $3^{\text {rd }}$ largest amount of cases of ovarian cancer in Asia; with mortality rate of 7,075 out of a total of 10,238 patients nationwide. There are several factors that are thought to influence the risk of ovarian cancer, one of them is the age of menarche. This study aims to determine the effect of menarche age on the incidence of ovarian cancer in Abdul Wahab Sjahranie Hospital Samarinda. This research is an observational analytic study with cross sectional design using purposive sampling technique. The research instrument was carried out using medical records. The results obtained as many as 82 respondents who met the inclusion and exclusion criteria where there were 20 patients diagnosed with ovarian cancer and 62 patients who were not diagnosed with ovarian cancer. The data was analysed using the Somer's $d$ test. The results showed that there was no influence of age of menarche on the incidence of ovarian cancer with the value of $p=0.323(p>0.05)$.
\end{abstract}

Keywords : Age of Menarche, Ovarian Cancer

\begin{abstract}
Abstrak
Kanker ovarium adalah kanker ke-7 yang paling umum dan penyebab kematian ke-8 paling umum pada wanita di seluruh dunia. Pada tahun 2012, Indonesia merupakan negara yang memiliki jumlah kasus kanker ovarium tertinggi ke tiga di Asia dengan jumlah kasus sebanyak 10.238 pasien dan jumlah mortalitas akibat kanker ovarium sebanyak 7.075 pasien. Terdapat beberapa faktor yang diduga dapat memengaruhi risiko terjadinya kanker ovarium, salah satunya ialah usia menarche. Penelitian ini bertujuan untuk mengetahui pengaruh usia menarche terhadap kejadian kanker ovarium di RSUD Abdul Wahab Sjahranie Samarinda. Penelitian ini merupakan penelitian observasional analitik dengan desain cross sectional dengan menggunakan teknik purposive sampling. Instrumen penelitian dilakukan dengan menggunakan rekam medik. Hasil penelitian didapatkan sebanyak 82 responden yang memenuhi kriteria inklusi dan eksklusi dimana terdapat 20 pasien yang didiagnosis kanker ovarium dan 62 pasien yang tidak didiagnosis kanker ovarium. Analisis data menggunakan uji Somer's $d$. Hasil penelitian menunjukan bahwa tidak terdapat pengaruh usia menarche terhadap kejadian kanker ovarium dengan nilai $p=0,323 \quad(p>0,05)$.
\end{abstract}

Kata Kunci : Usia Menarche, Kanker Ovarium 


\section{PENDAHULUAN}

Kanker adalah sekelompok penyakit yang ditandai oleh pertumbuhan yang tidak terkendali dan penyebaran sel-sel abnormal, jika penyebaran sel-sel tersebut tidak terkontrol, hal tersebut dapat mengakibatkan kematian (American Cancer Society (ACS), 2018). Kanker ovarium muncul dari sel-sel di ovarium atau tuba fallopi yang tumbuh secara tidak normal dan berlipat ganda yang kemudian membentuk benjolan atau tumor (Kstorfin Medical Communications Ltd (KMC), 2017). Diperkirakan pada tahun 2012 terdapat 239.000 kasus kanker ovarium dan 152.000 kematian di seluruh dunia akibat kanker ovarium (World Ovarian Cancer Coalition (WOCC), 2018).

Penyebab pasti kanker ovarium masih belum diketahui, tetapi beberapa faktor risiko penyakit ini telah teridentifikasi (KMC, 2017). Menurut hipotesis incessant ovulation, usia dini saat menarche meningkatkan risiko terjadinya kanker ovarium dengan meningkatkan jumlah siklus ovulasi (Reid, Permuth, \& Sellers, 2017). Hasil penelitian meta-analisis di Cina menunjukkan bahwa usia menarche berbanding terbalik dengan risiko kanker ovarium dengan pengurangan risiko sekitar 15\% (Gong, Wu, Vogtmann, Lin, \& Wang, 2014). Namun studi yang dilakukan di RSUD Labuang Baji Makassar melaporkan bahwa $75,76 \%$ dari total pasien kanker ovarium merupakan kelompok pasien dengan usia saat menarche $>12$ tahun (Lisnawati, 2014).

Angka kejadian kanker ovarium yang tinggi, hasil penelitian yang telah dilakukan tidak konsisten, dan penelitian mengenai pengaruh usia menarche terhadap kejadian kanker ovarium belum pernah dilakukan di Samarinda, maka peneliti tertarik untuk melakukan penelitian dan analisis data rekam medik pasien kanker ovarium di RSUD Abdul Wahab Sjahranie Samarinda guna mendapatkan informasi mengenai pengaruh usia menarche terhadap kejadian kanker ovarium di RSUD Abdul Wahab Sjahranie Samarinda.

\section{METODE PENELITIAN}

Penelitian ini dilakukan di Instalasi Rekam Medik RSUD Abdul Wahab Sjahranie Samarinda bulan Juli 2019 menggunakan desain penelitian observasional analitik dengan pendekatan cross sectional. Populasi penelitian ini adalah seluruh pasien yang di rawat inap di ruang Mawar di RSUD Abdul Wahab Sjahranie Samarinda bulan Januari sampai bulan Mei tahun 2019. Sampel dalam penelitian ini adalah pasien yang di rawat inap di ruang Mawar di RSUD Abdul Wahab Sjahranie Samarinda bulan Januari sampai bulan Mei tahun 2019 yang memenuhi kriteria inklusi. Jumlah sampel dalam penelitian ini adalah sebanyak 82 pasien dengan metode pengambilan sampel non random, yaitu dengan teknik purposive sampling. Sumber 
data yang digunakan dalam penelitian ini adalah data sekunder yang didapat dari data rekam medik pasien.

Adapun kriteria inklusi pada penelitian ini ialah pasien dengan data obstetrik yang lengkap pada rekam medik, sementara kriteria ekslusi pada penelitian ini ialah : 1) pasien dengan data rekam medik yang tidak dapat terbaca, 2) pasien yang belum pernah mengalami haid. Dalam penelitian ini digunakan satu variabel bebas dan satu variabel terikat. Variabel bebas dalam penelitian ini adalah usia menarche, sementara variabel terikatnya adalah kanker ovarium. Usia menarche sendiri didefinisikan sebagai usia pertama kali seorang wanita mengalami haid (Mutasya, Edison, \& Hasyim, 2016) dan kanker ovarium didefinisikan sebagai kanker ovarium yang

Tabel 1. Distribusi Karakteristik Responden

\begin{tabular}{|c|c|c|c|c|c|c|c|}
\hline \multirow[t]{2}{*}{ No. } & \multirow[t]{2}{*}{ Variabel Responden } & \multicolumn{2}{|c|}{ Kanker Ovarium } & \multicolumn{2}{|c|}{$\begin{array}{c}\text { Tidak Kanker } \\
\text { Ovarium }\end{array}$} & \multicolumn{2}{|c|}{ Jumlah } \\
\hline & & $\mathrm{n}$ & $\%$ & $\mathrm{n}$ & $\%$ & $\mathrm{n}$ & $\%$ \\
\hline \multirow{6}{*}{1.} & Usia & & & & & & \\
\hline & $<20$ tahun & 0 & 0 & 3 & 4,8 & 3 & 3,7 \\
\hline & 20-30 tahun & 0 & 0 & 11 & 17,7 & 11 & 13,4 \\
\hline & $31-50$ tahun & 11 & 55 & 33 & 53,2 & 44 & 53,7 \\
\hline & $>50$ tahun & 9 & 45 & 15 & 24,2 & 24 & 29,2 \\
\hline & Jumlah & 20 & 100 & 62 & 100 & 82 & 100 \\
\hline \multirow{4}{*}{2.} & Riwayat Abortus & & & & & & \\
\hline & Pernah Abortus & 6 & 30 & 24 & 38,7 & 30 & 36,6 \\
\hline & Tidak Pernah Abortus & 14 & 70 & 38 & 61,3 & 52 & 63,4 \\
\hline & Jumlah & 20 & 100 & 62 & 100 & 82 & 100 \\
\hline \multirow{4}{*}{3.} & Riwayat Menopause & & & & & & \\
\hline & Sudah Menopause & 2 & 10 & 5 & 8,1 & 7 & 8,5 \\
\hline & Belum Menopause & 18 & 90 & 57 & 91,9 & 75 & 91,5 \\
\hline & Jumlah & 20 & 100 & 62 & 100 & 82 & 100 \\
\hline
\end{tabular}

didiagnosis berdasarkan hasil pemeriksaan Patologi Anatomi.

Analisis data dilakukan secara univariat dan bivariat. Pada analisis univariat, data yang dikumpulkan akan dianalisis secara deskriptif untuk mengetahui sebaran data. Pada analisis bivariat, variabel bebas dan variabel terikat akan diuji signifikansi hubungannya dan korelasinya menggunakan uji Somer's d.

\section{HASIL DAN PEMBAHASAN}

Hasil

Penelitian ini dialakukan pada 82 pasien yang dirawat inap di ruang Mawar RSUD Abdul Wahab Sjahranie Samarinda dengan 20 pasien kanker ovarium dan 62 pasien tidak kanker ovarium. Distribusi karakteristik responden dapat dilihat pada tabel berikut : 
Berdasarkan tabel 1, dapat diketahui kelompok usia terbanyak pada responden yang terdiagnosis kanker ovarium ialah pada kelompok usia 31-50 tahun sebanyak 11 responden (55\%). Diketahui dari 82 responden, 30 responden pernah abortus dan 52 responden tidak pernah abortus. Responden yang terdiagnosis kanker ovarium mayoritas tidak pernah mengalami abortus, yaitu sebanyak 14 responden (70\%). Mayoritas responden belum mengalami menopause (75 responden) dan hanya terdapat 7 responden yang telah menopause. Responden yang terdiagnosis kanker ovarium mayoritas belum mengalami menopause, yaitu sebanyak 18 responden (90\%). Tabel 2. Distribusi Usia Menarche Responden

\begin{tabular}{lccc}
\hline \multirow{2}{*}{ Variabel Responden } & Kanker & Tidak Kanker & Jumlah \\
& Ovarium & Ovarium &
\end{tabular}

\begin{tabular}{ccccccc} 
& $\mathrm{n}$ & $\%$ & $\mathrm{n}$ & $\%$ & $\mathrm{n}$ & $\%$ \\
\hline $\begin{array}{c}\text { Usia Menarche } \\
<12 \text { tahun }\end{array}$ & 1 & 5 & 7 & 11,3 & 8 & 9,8 \\
$\geq 12$ tahun & 19 & 95 & 55 & 88,7 & 74 & 90,2 \\
$\quad$ Jumlah & 20 & 100 & 62 & 100 & 82 & 100 \\
\hline
\end{tabular}

Berdasarkan hasil penelitian didapat 82 responden, 8 responden $(9,8 \%)$ mengalami menarche dini di usia <12 tahun dan terdapat 74 responden $(90,2 \%)$ yang tidak mengalami menarche dini yaitu di usia $\geq 12$ tahun. Responden yang terdiagnosis kanker ovarium mayoritas mengalami menarche saat berusia $\geq 12$ tahun, yaitu sebanyak 19 responden (95\%) seperti yang terlihat pada tabel 2 .

\section{Berdasarkan}

hasil

pengolahan data, kelompok pasien yang terdiagnosis kanker ovarium menunjukan 1 pasien $(1,2 \%)$ yang usia menarchenya $<12$ tahun dan 19 pasien $(23,2 \%)$ yang usia menarchenya $\geq 12$ tahun. Kelompok pasien yang tidak terdiagnosis kanker ovarium menunjukan 7 pasien $(8,5 \%)$ yang usia menarchenya $<12$ tahun dan 55 pasien $(67,1 \%)$ yang usia menarchenya $\geq 12$ tahun seperti pada gambar 1 .

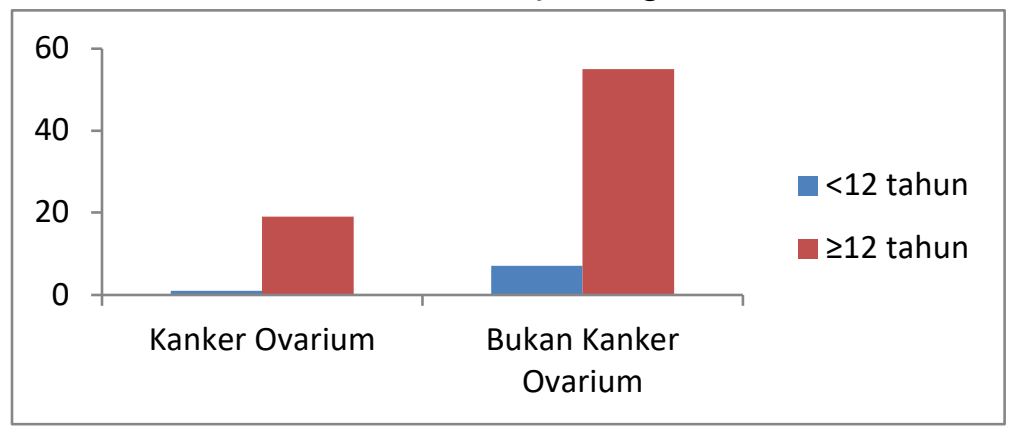

Gambar 1. Distribusi Usia Menarche dan Diagnosis Responden 
Tabel 3 menjelaskan mengenai tabulasi silang antara usia menarche dan kejadian kanker ovarium. Hasil penelitian menunjukan bahwa kanker ovarium 0,487 kali lebih berpeluang terjadi pada wanita yang mengalami menarche saat berusia $<12$ tahun dibandingkan pada wanita yang mengalami menarche saat berusia $\geq 12$ tahun. Nilai signifikansi (nilai $p$ ) yang didapat adalah 0,323. Hal tersebut menunjukan bahwa $p>0,05$,

Tabel 3. Hubungan Usia Menarche dengan Kejadian Kanker Ovarium

\begin{tabular}{ccccccccc}
\hline Usia & \multicolumn{9}{c}{ Kanker Ovarium } & \multirow{2}{*}{ PR } & Koefisien & \multirow{2}{*}{$\mathrm{Cl}$} & $\mathrm{P}$ \\
Menarch & \multicolumn{2}{c}{ Ya } & \multicolumn{2}{c}{ Tidak } & Korelasi & & \\
$\mathrm{e}$ & $\mathrm{N}$ & $\%$ & $\mathrm{~N}$ & $\%$ & & & & \\
\hline$<12$ & 1 & 1,2 & 7 & 8,5 & & & $0,075-$ & 0,323 \\
$\geq 12$ & 19 & 23,2 & 55 & 67,1 & 0,487 & -0.085 & 3,171 & \\
Total & 20 & 24,4 & 62 & 75,6 & & & & \\
\hline
\end{tabular}

\section{Pembahasan}

Hasil

penelitian

ini

menunjukkan bahwa tidak terdapat hubungan yang bermakna antara usia menarche dengan kejadian kanker ovarium. Hasil penelitian ini berbeda dengan hasil penelitian oleh Fachlevy, Abdullah, dan Russeng (2012) di Makassar yang menyatakan bahwa terdapat hubungan yang bermakna antara usia menarche dengan kejadian kanker ovarium. Perbedaan hasil penelitian ini bisa disebabkan oleh perbedaan jumlah sampel dan metode penelitian yang digunakan, dimana penelitian oleh Fachlevy, Abdullah, dan Russeng (2012) menggunakan metode penelitian case control dengan 204 pasien sebagai sampel penelitiannya. artinya tidak terdapat hubungan bermakna antara usia menarche dengan kejadian kanker ovarium, sehingga hipotesis $\mathrm{H} 1$ ditolak. Didapatkan koefisien korelasi sebesar -0,085 yang menunjukan korelasi negatif yang artinya semakin rendah usia menarche seseorang, maka semakin tinggi risiko mengalami kanker ovarium dan sebaliknya dengan kekuatan korelasi sangat lemah. 
Pada penelitian ini, didapati nilai $p$ sebesar 0,323 , artinya tidak terdapat hubungan yang bermakna antara usia menarche dengan kejadian kanker ovarium. Hal tersebut juga didapati pada penelitian oleh Koushik, et al (2016) di Kanada, dimana nilai $\mathrm{p}$ untuk hubungan usia menarche dan kejadian kanker ovarium didapatkan sebesar 0,95. Penelitian oleh Kurian, Balise, McGuire, \& Whittemore (2005) juga menunjukan bahwa tidak satupun dari jenis histologi kanker ovarium memiliki hubungan yang bermakna dengan usia menarche. Menurut hasil penelitian oleh Wentzensen, et al (2016) usia menarche tidak memiliki hubungan yang bermakna pada setiap jenis histologi kanker ovarium kecuali subtipe tumor clear cell. Hasil ini menunjukkan bahwa hipotesis mekanisme yang saat ini banyak digunakan seperti hipotesis incessant ovulation, tidak berlaku sama untuk setiap jenis kanker ovarium. Jumlah ovulasi seumur hidup seorang wanita merupakan hal yang memiliki pengaruh yang besar dalam risiko terjadinya kanker ovarium. Variabel yang menentukan jumlah ovulasi seumur hidup seorang wanita sendiri memiliki heterogenitas yang signifikan di seluruh subtipe kanker ovarium (Wentzensen, et al., 2016).

Penelitian Tsidilis, et al (2011) juga menyatakan bahwa tidak terdapat hubungan antara usia menarche dengan kejadian kanker ovarium. Hasil penelitian ini menunjukkan bahwa meskipun tidak ada hubungan antara usia menarche dan risiko terjadinya kanker ovarium, usia lanjut saat menopause dan durasi siklus menstruasi kumulatif seorang wanita secara positif terkait dengan risiko terjadinya kanker ovarium. Jika jumlah siklus menstruasi penting dalam perkembangan kanker ovarium seperti yang telah diusulkan pada penelitian-penelitin sebelumnya, terdapat kemungkinan bahwa perbedaan 1 atau 2 tahun pada usia menarche tidak akan memberikan kontribusi yang cukup besar terhadap jumlah siklus menstruasi seumur hidup (Tsilidis, et al., 2011).

\section{SIMPULAN}

Berdasarkan hasil penelitian dan pembahasan yang telah diuraikan peneliti menyimpulkan bahwa usia menarche tidak berpengaruh terhadap kejadian kanker ovarium di RSUD Abdul Wahab Sjahranie Samarinda. Saran yang diajukan untuk penelitian mengenai kanker ovarium di masa mendatang, yaitu perlunya pendataan secara lengkap mengenai karakteristik dari pasien yang dirawat di RSUD Abdul Wahab Sjahranie Samarinda seperti usia menarche, usia menopause, jenis kontrasepsi yang digunakan, lama penggunaan kontrasepsi yang digunakan, serta perlu dilakukan penelitian dengan sampel yang lebih banyak atau penelitian menggunakan desain case control 
untuk mengetahui pengaruh usia menarche terhadap kejadian kanker ovarium.

\section{DAFTAR PUSTAKA}

American Cancer Society. (2018).

Fachlevy, A. F., Abdullah, Z., \& Russeng, S. R. (2012). Faktor Risiko Kanker Ovarium di RSUP Wahidin Sudirohusodo Makassar. Retrivied from https://studylibid.com/doc/5873 95/faktor-risiko-kankerovarium-di-rsup-wahidin

Gong, T. T., Wu, Q. J., Vogtmann, E., Lin, B., \& Wang, Y. L. (2014). Age At Menarche and Risk of Ovarian Cancer: A Meta-Analysis Of Epidemiological Studies. International Journal of Cancer, 132(12): 2894-2900. doi:10.1002/ijc.27952.

Koushik, A., Grundy, A., Abrahamowicz, M., Arseneau, J., Gilbert, L., Gotlieb, W. H., ...Seimiatycki, J. (2016). Hormonal and Reproductive Factors and the Risk of Ovarian Cancer. Cancer Causes Control. 28(5):393403. doi:10.1007/s10552-0160848-9

Kstorfin Medical Communications Ltd. (2017).

Kurian, A. W., Balise, R. R., McGuire, V., \& Whittemore, A. S. (2005). Histologic Types of Epithelial Ovarian Cancer: Have They Different Risk Factors. Gynecologic Oncology 96, 520-530.
Lisnawati. (2014). Gambaran Faktor-Faktor Risiko Penderita Kanker Ovarium di RSUD. Labuang Baji Makassar Tahun 2013. Retrivied from http://repositori.uinalauddin.ac.id/6866/ Mutasya, F. U., Edison, \& Hasyim, H. (2016). Faktor-Faktor yang Berhubungan dengan Usia Menarche Siswi SMP Adabiah. Jurnal Kesehatan Andalas, 233-237.

Reid, B. M., Permuth, J. B., \& Sellers, T. A. (2017). Epidemiology of Ovarian Cancer: A Review. Cancer Biol Med, 9-32.

Tsilidis, K., Allen, N., Key, T., Dossus, L., Lukanova, A., Bakken, K., ... Riboli, E. (2011). Oral Contraceptive Use and Reproductive Factors and Risk of Ovarian Cancer in the European Prospective Investigation into Cancer and Nutrition. British Journal of Cancer, 1436-1442.

Wentzensen, N., Poole, E. M., Trabert, B., White, E., Arslan, A. A., Patel, A. V., ...Tworoger, S.S. (2016). Ovarian Cancer Risk Factors by Histologic Subtype: An Analysis From the Ovarian Cancer Cohort Consortium. Journal Of Clinical Oncology, 34(24):2888-98. doi:10.1200/JCO.2016.66.8178 World Ovarian Cancer Coalition. (2018). 